\title{
FINANCIAL DEVELOPMENT AND ECONOMIC GROWTH: PANEL CROSS - COUNTRY STUDY
}

\author{
SYED FAREED ULLAH \\ Pakistan Institute of Development Economics, Islamabad, Pakistan \\ SHAHID MANSOOR HASHMI \\ National Institute of Banking and Finance, Islamabad, Pakistan
}

\begin{abstract}
This study aimed to examine the effect of financial development (FD) and private credit booms on economic growth. This study used the data of 58 countries (27 DCs and 31 LDCs), from the period 1973 to 2012, by applying the method of Panel Cointegration. This study involved the FD index made of four indicators of banking sector depth, activity, and efficiency indicators. The estimation results showed that LDCs gave more positively significant response to FD than DCs. This is because the LDCs' financial systems are dominantly Bank based or their banking sector is more developed than other institutions and markets. Whereas, the credit boom to private sector (which is taken as indicator of FD) inversely affect the economic growth rate. Such relation can be caused by lack of credit recovery, more defaulting loans, insolvency, and huge public debt, that hence leads to a financial crash like that of 2008 financial crisis.
\end{abstract}

\section{INTRODUCTION}

The phenomenon of financial development (FD) can be defined as"the policies, factors, and the institutions that lead to the efficient intermediation and effective financial markets. A strong financial system offers risk diversification and effective capital allocation. The greater the FD, the higher would be the mobilization of savings and its allocation to high return projects and potential investments that further accelerates the process of economic growth.

The pioneers of the development economics accompanied with three Nobel Laureates, who are"Lucas (1988), Robinson (1952), and Miller (1998), stressed a lot to the literature of finance-growth nexus. According to Lucas (1988), "The economists over-stressed the role of financial system in the economic growth". Similarly, Robinson (1952) argued that "Finance follows where enterprise leads", which means it is the economic growth which induces incentives and demand for the financial services, and financial system responds to these demands, nothing else. On the other hand, Miller (1998) stated that "Financial markets contribute to growth is a proposition too obvious for serious discussion". Similarly, argued by Bagehot (1873), Schumpeter (1911), Gurley and Shaw (1955), Goldsmith (1969), McKinnon (1973), financegrowth nexus cannot be ignored while understanding the idea of economic growth.
The focus of the study is on one pole of the financial sector i.e. the financial intermediaries sector of the economies. The reason is to be specific and concise.

The objective of this study is to examine the impact of financial development in the intermediaries sector on economic growth. Moreover, the forecasting signals for occasional financial crisis due to credit booms in advancing credit to private sector would also be examined."In light of the existing literature on finance-growth nexus, the following will contribute to the existing literature in the following ways:"by examining FD and economic growth, by introducing a newly constructed index of FD; and assessing the forecasting signals for occasional financial crisis which is induced due to high credit growth to private sector."This study would help the researchers and financial analysts to analyse different financial systems at a given time, and also over the time periods. It can also help them to compare different country's FD with given GDP per capita income.

\section{LITERATURE REVIEW}

We are well aware about the integral debate of today's world among the policy makers and economic think-tanks, especially in the financial sector, that how much the financial sector development is essential in the development of an economy. "There is a lot of literature on different aspects of finance-growth linkages, and they 
are agreed on the point that there is a relation between finance and growth. However, they disagree on the direction of the finance-growth relation, such that either FD leads to economic growth or vice versa. Financial sector development leads to economic growth, either by endogenous or exogenous channels in both long-run and short-run paths."

The empirical literature documents a significant and positive relationship between financial intermediaries' sector development and economic growth, like King and Levine (1993) presented the simultaneous relationship between FD and the growth indicators and sources of growth from the period of 1960 to 1989 across 80 countries. They studied whether the average level of FD is significantly and robustly correlated with faster current and future average rate of real per capita GDP growth, the rate of physical capital accumulation, and the rate of improvement in economic efficiency. They applied both two-stage least square (2SLS) and three-stage least square (3SLS) for using initial values of development and growth determinants."Their results showed that higher levels of FD are positively associated with faster rates of economic growth, physical capital accumulation, and economic efficiency improvements, as well as for the future time period, both before and after controlling for numerous country and policy characteristics. "Their results found that indicators of FD, like; the size of the formal financial intermediary sector relative to GDP, the importance of banks relative to the central bank, the percentage of credit allocated to private firms, and the ratio of credit issued to private firms to GDP, are highly correlated with growth, the rate of physical capital accumulation, and improvements in the efficiency of capital allocation. They also found that the predetermined components of these FD indicators significantly predict succeeding values of the economic growth indicators."

In addition to this study, Beck, Levine, and Loayza (1999) took the sample of 74 countries from period of 1960 to 1995 . They applied the methods of Generalized Method of Moments (GMM) and cross-sectional Instrumental Variable estimators (by taking legal origins as instrumental variables). Their results argued that financial intermediary development pulls a significant and positive impact on total factor productivity growth, which further fuels, in general, the GDP growth. Moreover, the results were consistent with the Schumpeterian view that the intensity of FD significantly determines the rate of economic growth by affecting the speed of productivity growth and technological change. The same results were given by Khan et al. (2005) in their study, by applying the technique of Autoregressive distributed Lag (ARDL) accompanied with Error Correction model (ECM) and Cointegration technique, from the period of 1971 to 2004 in Pakistan.
The study with same estimation techniques as of Khan, Qayyum, \& Sheikh (2005), except Error Correction model (ECM), was taken by Jalil and Ma (2008). They attempted to assess the relationship between FD and economic growth in case of China and Pakistan from the period of 1960-2005. They conducted Bonds testingARDL Co-integration approach to investigate the existence of long run relationship between FD and economic growth. They used banks deposit liquid liabilities ratio and private credit ratio as indicators for FD. They observed in their results that there exists a strong significant relationship between the FD indicators and economic growth, in both countries.

In Pakistan, they observed that there exists a significant relationship between both FD indicators with economic growth, and that there is significant impact of FD on economic growth. While in case of China, one indicator shows insignificant impact on economic growth. Jalil "and Feridun (2011) examined the same study in China only from the period 1978 to 2006 and applied only ARDL by introducing a financial depth indicator to measure the development of financial sector by using Principal Component Analysis (PCA). They observed that there is a significant positive long-run relationship between FD and economic growth. They also demonstrated that there is one way relationship between FD and economic growth, or FD is interpreted as a long run determinant of economic growth instead, and vice versa.

In the literature of finance-growth nexus, the study of Shan (2006) is different from the previous work, i.e., by taking into account innovation accounting or impulse response function and variance decomposition analysis, to examine the dynamic relationship between FD and economic growth. He took the quarterly time series data for 10 OECD countries accompanied with China from 1985 to 1998 and applied the technique of VAR. Here, he introduced a new proxy of total credit to measure the FD. Furthermore, to assess whether FD leads to economic growth or not, in other words whether FD granger causes economic growth or not.

It was found from his results of Variance Decomposition analysis that FD leads to growth in most of the countries in the sample, but with some considerable differences between Western countries that have more developed financial systems and the Asian countries with less developed financial systems. The results showed that FD is no more than a causal factor and, almost definitely, not the most chief factor. It was cleared that causality might exists, but there might be un-uniform direction. Hence, the statement hypothesis of FD leads to economic growth may not be generally supported by time-series analysis too.

The development literature documented another study of finance-growth nexus which used a different estimation 
methodology to solve this issue. Hassan, Sanchez, and Jung-Suk Yu (2011) presented the indication of the role of FD for economic growth, taking into account the lowincome, middle-income, and high-income countries. They took the sample of 168 countries from 1980 to 2007. Their study examined the imperative proxy measures of FD, and to what extent they contribute to explaining the economic growth across geographic regions and income groups. They applied both panel regressions for each of the six regions and two high income groups, and also for the overall pooled data by Weighted Least Square (WLS). Their study was aimed to assess the relationship and direction of the FD and economic growth, for this purpose they applied VAR."

Their results inferred that there is a positive relationship between FD and economic growth in LDCs. It was found that "in the short run, there is a two-way Granger causality between FD and economic growth for most of the regions. However, it is not in Sub-Saharan Africa and East Asia \& Pacific countries, where there is a one-way Granger causality that flows from economic growth to FD, being the lowest-income countries. It might be due to the fact that there is high demand of financial services, which leads to FD. It is also seen that trade and government consumption plays a crucial role in determining the economic growth in LDC's. So, that's why FD might not be the only motive for the enhancement of economic growth in developing countries."

The studies based on the cross section and panel data are found to be have positive effects of FD on growth, even after accounting for other determinants of growth, as well as for potential biases induced by "simultaneity, omitted variables, and unobserved country-specific effects on the finance-growth nexus. On the other hand, the studies based on the time series data gave contradictory results. Demetriades and Hussein (1996) found the evidence that finance is a leading factor in the process of economic growth." They further found that for the majority of the countries, causality is bi-directional, while in some cases FD follows economic growth, while"Luintel and Khan (1999) used a sample of 10 LDC's and concluded that causality between FD and output growth is bi-directional for all countries.

Finally, studies, which look at the structure and sources of company finance, also conclude that the development of the financial sector facilitates the growth of corporate sector (Rajan \& Zingalas, 1996).

Since this study is concentrated merely to examine that how financial intermediary's sector development leads to fuel the economic growth; so, we elucidate the theoretical links that how and by which channels financial intermediaries' sector development affects economic growth. Since, financial development refers to "the policies, factors, and the institutions that lead to the efficient intermediation and effective financial markets; however, by FD we don't mean that it totally eliminates market imperfections, but it helps to reduce the degree of market imperfections y easing the access to information, access to financial services and instruments, reducing comparatively the transaction costs that makes the financial institutions and markets efficient having effective legal and regulatory system, which further leads to the development of financial institutions and markets (having greater risk diversification), and that attracts the potential investors to invest in high-return projects with diversified portfolios, which therefore leads to foster economic development.

\section{Positive relationship between Financial Development and Growth}

The basic idea that how the financial system affects the process of economic growth was primarily given by the pioneers of finance-growth nexus i.e. "Bagehot (1873), Schumpeter (1911), Debreu (1959), Arrow (1964) and Patrick (1966), who stated that financial system plays a very vital role in fostering economic growth by enhancing innovative activities and efficient capital allocation, by identifying the best investment opportunities. Furthermore, financial system affects the process of growth positively in a sense that the financial institutions evaluate the potential investors, and then funnel funds from small savers to those potential investors' investment, further by diversifying the risk associated with innovative activities of those investments efficiently.

Hence, the more the financial institutions perform their function of evaluating, diversifying risk, and crediting efficiently, the more it will accelerate the process of economic growth (King \& Levine, 1993). "In other words, better financial system enhances economic growth by stimulating the rate of productivity enhancement." (Greenwood \& Jovanovic, 1990; Levine (1991); Bencivenga \& Smith, 1991; Boyd \& Smith, 1992; SaintPaul, 1992; Pagano, 1993).

To assess the impact of FD on economic growth, most of the theoretical framework suggests that "we can better know the relation by examining through the primary functions provided by the financial institutions, and to link it with economic growth process. So, to do so there is one basic primary function performed by the financial institutions to improve and to mitigate the information costs, transaction costs, and other financial frictions, i.e., "To facilitate the resource allocation across space and time efficiently, in an uncertain environment." (Merton \& Bodie, 1995, p.12). To elucidate more, this primary function of the financial institutions, we decomposed this primary function into five primary functions. In particular, the financial systems: "facilitate the trading, hedging, 
diversifying, and pooling of risk, allocate resources, scrutinize and monitor managers and exert corporate control, savings mobilization, and facilitate the exchange of goods and services.

The theory demonstrates that there are basically two channels through which these financial functions (subfunction of primary function) may affect the economic growth, (i) Capital allocation and (ii) Technological innovation. Capital allocation channel demonstrates that innovations in the telecommunications, and computing have definitely affected the financial sector, and hence fuels the growth process. Many growth models documented that the functions of the financial institutions have an effect on the process of economic growth, by influencing on the rate of capital formation, which came from the high level of spurred investment, which is the result of huge savings enhanced by the financial intermediaries. However, the class of growth models put immense concentration on the enhancement of technological progress and innovations, and demonstrated that these are the core steps to be taken in order to promote the growth and prosperity in the economy. "These models mainly focused on the invention of new production processes and technologies, which leads to making variety of differentiated, brand, and focused goods for different consumer groups. More precisely, these models revealed that financial institutions via its primary functions alter the growth rate by changing the rate of technological innovation, specifically in the long-run (Romer, 1990; Grossman \& Helpman, 1991; Aghion \& Howitt, 1992).

Keynes (1930) amplified the importance of financial intermediaries sector on economic growth as: the credit provided by the banks paves the way for productive investments, or capital allocation and the bankers would provide the transport facilities in order that the productive powers of the community can be employed at their full capacity. The FD may affect positively the growth rate by producing better information to the economic agents, and by easing or alleviating the financial frictions that helps in shaping firms' decisions and adopting innovative incentives with better ramifications (Gurley \& Shaw, 1955; Patrick, 1966; Greenwood \& Jovanovic, 1990; Saint-Paul, 1992; Devereux \& Smith, 1994; Obstfeld, 1994).

Pagano (1993) suggested that there are, basically, three channels which can contribute to assess the impact of FD on economic growth. Firstly, through a raise in the proportion of savings that is induced for the purpose of stimulating the investment level. Hence, this process of raising savings, which funnelled to investment, involved that the financial intermediaries absorb some fraction of savings by considering it as the spread between lending rate and borrowing rate in banking sector, while as a reward for services supplied (as commission or fees for brokers and dealers) in securities market. On the other side, such activities of financial markets are influenced by some factors like, taxation, restrictive regulations, and other Govt. policies, in case of high amount of transactions.

To make it simple, it is pretended that the Quasi-rent earned by the financial intermediaries are almost spent on the private consumption, and the tax revenue earned by the Govt. is entirely to be spent on the public consumption. So, the policy implications hereof are to consume or spent entirely or partly of the earning to stimulate investment, followed by accelerating the process of growth. In sum, the core purpose of FD is to reduce this resource absorption from the savings, or to increase the proportion of saving that is to be funnelled to investment, and hence to foster the economic growth. In addition, this can be done through raising the productivity level of capital by allocating resources to those investment projects whose marginal productivity of capital is high, which leads to accelerate growth via two roles: one is through information role, and second is through risk sharing role.

The information role involves the collection of information for evaluating the alternative investment projects; whereas, the "risk sharing role involves the provision of risk sharing opportunities by the financial intermediaries, which influences the behaviours of the savers to save, and have choices to invest in most productive portfolios (Levine, 1991 \& Saint-Paul, 1992). This channel is through stimulating the private savings rate. The theory states that, as the capital markets get mature, it infers that the credit for consumers will be cheaply and readily available on demand. It encourages the households to invest more to have high returns and they might get further insurance against their investment projects, by diversifying their risk associated with the rate of return, and henceforth fosters the growth rate."

The theoretical literature postulates that "financial sector development spurs economic growth. In fact, due to the existence of a well-functioning financial system, which follows the efficiency in the financial sector, leads to a decline in the cost of capital, information costs, transaction costs, monitoring and $\mathrm{R} \& \mathrm{D}$ costs. A wellfunctioning financial institution fuels the business and investment opportunities, by funnelling saving funds to well diversified portfolios, efficient resource allocation, and development of human and physical capital, and technological innovation that paves the way for economic development.

The development of financial sector also concerns about the well managed system of monitoring and mobilization of funnelling funds, management performance, and risk taking in the exchange of goods and services (Creane, Goyal Rishi, Mushfiq, \& Randa, 2004). The theory postulates that the greater the FD in the economy, the greater would be the financial services and 
project returns, and the lower would be the information acquisition costs and risks, and more would be the faith in the forecasting in the financial institutions.

In sum, the function of FD is "producing and processing information about possible investments and allocating capital. These are based on assessments, monitoring individuals and firms, and exerting Cooperate governance after allocating capital, facilitating the trading, diversification, management of risk, mobilizing and pooling savings, and easing the exchange of goods and services and financial instruments." However, the degree of FD around the World varies in the provision of these key functions. The financial institution that provides these functions efficiently leads to improvement in the allocation of capital. This, hence, accelerates economic growth, by following an expansion of economic opportunities, encourages an entry of new competent, and intends to expel out the less efficient firms from the market, accompanied by better governance and accountability.

\section{Negative relationship between Financial Development and Growth}

As financial markets shares endowment risks "(such as health hazards) and the risk associated with the rate of return; hence, individuals may counter these risks via securities markets, if exists. Moreover, by assuming that the securities markets are fulfilling constant relative risk aversion and the individual's purpose is for precautionary needs, then the individuals will save less against their precautionary demands in the future. Therefore, it leads to a decline in the saving rate and hence the growth rate, due to FD. This decline in the saving rate may at least offset the growth enhancing effects of more productive investments (Pagano, 1993).'The same demonstration has been pointed out by "Devereux and Smith (1991). Moreover, as the FD improves the risk diversification, so lower risk may also ambiguously affect savings in a growth model when it is accompanied with physical capital externalities, thereby retards the process of growth and welfare level (Levine (2003); Levhari \& Srinivasan, 1969).

\section{Zero relationship between Financial Development and Growth}

The statement of Robinson (1952) that "where enterprise leads, finance follows", which means that economic growth is not affected by FD, instead economic growth induces incentives for a rise in the demand of financial services and financial system responds to these demands simply. The same view has been pointed out by Lucas (1988). He stated that economists "“"badly over stressed"" the importance of the financial system in the process of growth. In fact, he predicted that the financial services were merely the sideshow for the economic growth process. Robinson (1952) also derived some sceptical views from the Neo-Classical growth models which stressed that financial institutions have a very minor effect on the enhancement of economic growth; rather it is the side-show of the growth process. That is, it affects the level of investment, which is considered to be the prime contributor towards accelerating economic growth.

Similarly, Rajan and Zingales (1998) argued that FD leads to economic growth or a causal factor, but it can be a leading factor in the growth process, nothing else. They also stressed that they cannot simply identify its effects on growth because at the same time the country is passing through various structural transformation processes. This idea was also given by Ram (1999); Kemal, Qayyum, and Hanif (2004).

\section{Endogenous relationship of Financial Development with Growth}

The endogenous growth models also takes into account the role of financial sector within the framework of new growth theories, which stresses the role of financial intermediation and development as an endogenous process. These models also stress that both can affect each other simultaneously. "The growth process motivates the economic agents to participate in the financial institutions, and hence enhances facilitating the establishment and promoting the intermediaries sector. On the other side, this promotion of intermediaries sector enhances an efficient allocation of capital towards potential investments, and hence fosters the growth process (Greenwood \& Jovanovic, 1990).

Other growth models show that financial intermediaries have some real resources costs (fixed costs) or "resources less than proportional to the volume of funds intermediated. This augments the economy's capacity to grow, which further increases an incentive for the individual to participate in the financial markets, and henceforth spurs the financial sector endogenously (see Robinson, 1952; Kuznets, 1955; Freidman \& Schwartz, 1963; Greenwood \& Jovanovic, 1990; SaintPaul, 1992).

It is of immense interest to document the hypothesis of the research that what we are going to confirm from this study. They are:

\section{Hypothesis 1. FD leads to fuel the pace of eco- nomic growth. \\ Hypothesis 2. There exists a long run relationship between FD and economic growth. \\ Hypothesis 3. Private credit booms after thresh- old level may also hurt the economy.}




\section{RESEARCH METHODOLOGY}

For this study, real GDP per capita growth rate (proxy for economic growth rate) as dependent variable was employed,and regressed it on FD indicators accompanied with other control variables. The general model specification form is as:

$$
\mathrm{Y}_{\mathrm{i}, \mathrm{t}}=\beta_{\mathrm{o}}+\beta_{1} \Sigma \mathrm{X}_{\mathrm{i}, \mathrm{t}}+\beta_{2} \mathrm{FD}_{\mathrm{i}, \mathrm{t}}+\varepsilon_{\mathrm{i}, \mathrm{t}}
$$

Where $\mathrm{Y}_{\mathrm{i}, \mathrm{t}}$ shows the real GDP per capita growth rate. $\Sigma X_{i, t}$ is a vector that indicates the summation of controlled variables which shows other determinants of growth rate, which include: inflation rate (inf), secondary school enrolment (SSE), population growth rate(pop), real interest rate (RIR), log of life expectancy (life), and trade openness (trade), and $\beta_{1}$ is the coefficient parameter for those control variables. Moreover, $\mathrm{FD}_{\mathrm{i}, \mathrm{t}}$ shows the $\mathrm{FD}$ index, constructed from four measures through the method of Principal Component Analysis (PCA), aimed to achieve a single and meaningful index out of complex and multidimensional elements of FD and to re-express the data with minimum noise and maximum extract to measure the strength of FD. These indicators indicates various characteristics of financial institutions; such indicators are: ratio of broad money to GDP---Financial Depth, which shows how deep the financial intermediaries sector is; private credit to GDP and banks assets to banks and central bank assets ---Financial
Intermediation or activity, which shows saving mobilization and credit allocation role of financial intermediaries or activity of the financial intermediaries sector; interest rate spread---Financial efficiency, which shows efficiency of financial intermediaries in intermediating resources and facilitating financial transactions.

This study used the method of Fully Modified Ordinary Least Square (FMOLS) also suggested by Pedroni (2000), which is a new technique to account for endogeneity (also account for heterogeneity and autocorrelation among the individuals caused by individual effects), and also where there exists a long-run relationship between the main variables i.e. FD and economic growth. This method is advantageous in a sense that it allows researchers to selectively pool long run information and short run dynamics along with fixed effects to be heterogeneous among different members of the panel. In addition, it produces asymptotically unbiased estimators and irritant parameter free standard normal distribution (Pedroni, 1999). The data sample consists of 58 countries across the World, among which 27 are Developed Countries (DCs) and 31 are Developing Countries (LDCs), while the sample period was taken from 1973 to 2012. Most of the data was taken from World Bank's World Development Indicators (WDI). The other sources include Global Financial Development Database (GFDD), and from the studies of Caprio and Klingebiel (2003), Laeven and Valencia (2012), and Čihák, Demirguc-Kunt, Feyen, and Levine (2013), etc.

TABLE 1

Im, Pesaran, \& Shin (1997) Panel Unit Root Tests

\section{Developed Countries}

\begin{tabular}{lllll} 
Variable & Statistic & Prob. & Statistics & Prob. \\
\hline Currency & -16.7627 & 0.0000 & -11.7190 & 0.0000 \\
Depth & -19.0252 & 0.0000 & -28.4682 & 0.0000 \\
FD index & -19.8104 & 0.0000 & -19.8104 & 0.0000 \\
FDI & -33.9901 & 0.0000 & -33.6364 & 0.0000 \\
Govt. & -21.5911 & 0.0000 & -28.2424 & 0.0000 \\
Inf & -6.59208 & 0.0000 & -14.4163 & 0.0000 \\
Inv. & -27.2098 & 0.0000 & -35.8628 & 0.0000 \\
Life & -32.7568 & 0.0000 & -4.04862 & 0.0000 \\
Pop & -21.9070 & 0.0000 & -9.23052 & 0.0000 \\
Private & -17.8872 & 0.0000 & -20.2110 & 0.0000 \\
RIR & -30.3088 & 0.0000 & -32.9830 & 0.0000 \\
Spread & -24.3230 & 0.0000 & -22.0121 & 0.0000 \\
SSE & -20.3543 & 0.0000 & -17.8760 & 0.0000 \\
Trade & -25.4879 & 0.0000 & -30.7171 & 0.0000 \\
Y & -31.5280 & 0.0000 & -39.7123 & 0.0000 \\
\hline
\end{tabular}

Null hypothesis: there is unit root (no stationarity)

Alternative Hypothesis: there is no unit root (stationarity)

Sample: 19732012

User-Specified lag length: 
TABLE 2

Pedroni Residual Cointegration Test

Developed Countries

Developing Countries

Alternative hypothesis: Common AR coefficients (within-dimension)

\begin{tabular}{|c|c|c|c|c|c|c|c|c|}
\hline & Statistic & Prob & $\begin{array}{l}\text { Weighted } \\
\text { Statistic }\end{array}$ & Prob & Statistic & Prob & $\begin{array}{l}\text { Weighted } \\
\text { Statistic }\end{array}$ & Prob \\
\hline Panel v-statistic & 0.031353 & 0.4875 & -2.244287 & 0.9876 & -0.830864 & 0.7970 & -3.752437 & 0.9999 \\
\hline Panel rho-statistic & -0.420744 & 0.3370 & 0.570547 & 0.7158 & -4.566141 & 0.0000 & -2.171319 & 0.0150 \\
\hline Panel pp-statistic & -11.58677 & 0.0000 & -11.72420 & 0.0000 & -18.72957 & 0.0000 & -18.03345 & 0.0000 \\
\hline Panel ADF-statistic & -7.461867 & 0.0000 & -7.992615 & 0.0000 & -8.446791 & 0.0000 & -9.461613 & 0.0000 \\
\hline \multicolumn{9}{|c|}{ Alternative hypothesis: Individual AR coefficients (between-dimension) } \\
\hline & Statistic & Prob & & & Statistic & Prob & & \\
\hline Group rho-statistic & 2.492585 & 0.9937 & & & 0.025913 & 0.5103 & & \\
\hline Group pp-statistic & -18.46782 & 0.0000 & & & -26.18743 & 0.0000 & & \\
\hline Group ADF-statistic & -7.460819 & 0.0000 & & & -9.512586 & 0.0000 & & \\
\hline
\end{tabular}

Series: Y RIR INF LIFE SSE TRADE FD, Sample: 1973 2012, Null hypothesis: No Cointegration, User-specification lag length: 1, Newey-West automatic bandwidth selection and Bartlett kernel

TABLE 3

The effect of Financial Development on Economic Growth

\begin{tabular}{lllll}
\hline Variables & DC's & LDC's & DC's & LDC's \\
\hline RIR & -0.041 & $0.050^{*}$ & $-0.092^{*}$ & $-0.020^{* * *}$ \\
Inf & $3.829^{*}$ & -0.139 & $-0.874^{*}$ & $-0.622^{* *}$ \\
Pop & $-2.042^{*}$ & $-1.084^{* *}$ & $-0.951^{*}$ & $-0.769^{* * *}$ \\
Life & $101.751^{* *}$ & $55.14^{*}$ & $118.83^{*}$ & $18.442^{* *}$ \\
SSE & $2.382^{* * *}$ & $1.374^{* * *}$ & $5.247^{*}$ & $3.074^{* *}$ \\
Trade & $17.502^{*}$ & $30.85^{*}$ & $14.118^{*}$ & $7.74^{*}$ \\
FD index & $0.778^{*}$ & $2.628^{*}$ & & \\
Inv. & $5.788^{*}$ & $2.473^{*}$ & & \\
FDI & $3.19^{*}$ & $4.165^{*}$ & & \\
Govt. & -6.705 & $-33.646^{*}$ & & \\
Banking & $-0.901^{* *}$ & -0.731 & & \\
Currency & -5.534 & $-8.85^{*}$ & & \\
Debt & & $-3.333^{*}$ & & \\
Private & & & $17.66^{*}$ & 2.36 \\
Private2 & & & $-6.015^{*}$ & $-3.072^{* *}$ \\
$\mathrm{R}^{2}$ & 0.68 & 0.762 & 0.339 & 0.286 \\
\hline
\end{tabular}

Dependent variable is real GDP per capita growth rate ( $Y_{-}$ $(i, t))$, RIR in the real interest rate, Inf is the Inflation rate, Pop is the Population growth rate, Life is the log of life expectancy at birth, SSE is the secondary school enrolment ratio, Trade is the trade openness (exports + imports / GDP), FD index is the aggregate index of financial development, Inv is the domestic investment to GDP, Govt is the Government expenditures to GDP, FDI is the foreign direct investment inflows, Banking and Currency, Debt are the dummy variables of Banking crisis, Currency crisis, and Debt crisis, respectively. Private is the credit to Private sector to GDP, and Private2 is the square of Private credit to GDP., DC and LDC stands for Developed Countries and Least Developing Countries, respectively., Statistical significance at $1 \%, 5 \%$ and $10 \%$ is denoted by*, ** and $* * *$ respectively.

This study involves the test for stationarity by applying Panel Unit root test of Im, Pesaran, and Shin (1997), to find out whether they the variables are stationary at level, first difference, or lag of the difference. It also involves a test of Panel Cointegration by Pedroni $(1997,1999)$ to check out the cointegrating vectors in the panel.

\section{RESULTS AND DISCUSSION}

Before delving into presenting the estimation results of Panel Cointegration, we need to indicate the tests statistics of stationarity tests and Cointegration tests (to check out whether the variables are integrated in the same order or not), and then the regression results.

The test results of Im et al., (1997) states that all the variables are stationary at their first difference. So, the null hypothesis of no stationarity is rejected at $1 \%$ significance level, and the alternative hypothesis is accepted. The test statistics of Panel Unit root tests are presented in Table 2 for both DCs and LDCs, where the test results of Pedroni $(1997,1999)$ postulates appropriate test statistics of the given seven statistics. Most of the test statistics of results states that the null hypothesis of no Cointegration is rejected which is given by the p-value, that is less than 0.05 for most of the test statistics out of seven test statistics in the table (Table 2). Hence, it is concluded that the models have Cointegration which means the variables in the models are cointegrated in the same order (Asteriou \& Hall, 2011). 
TABLE 4A

The Effect of Financial Development on Economic Growth

\begin{tabular}{|c|c|c|c|c|c|c|}
\hline \multirow[b]{2}{*}{ Variables } & \multicolumn{5}{|c|}{ Estimated Regressions } & \multirow[t]{2}{*}{ (27 - Developed Countries) } \\
\hline & 1 & 2 & 3 & 4 & 5 & \\
\hline RIR & $-0.097^{*}$ & $-0.096^{*}$ & $-0.108^{*}$ & $-0.043 * * *$ & $-0.098^{*}$ & $-0.117 *$ \\
\hline Inf & $4.103 *$ & $4.027 *$ & $4.252 *$ & $4.248^{*}$ & $4.665^{*}$ & $-1.404 *$ \\
\hline Pop & $-1.011^{*}$ & $-1.031^{*}$ & $-1.250^{*}$ & $-1.116^{*}$ & $-0.748^{*}$ & \\
\hline Life & $80.830 *$ & $79.283^{*}$ & 36.488 & 25.572 & 65.516 & $117.71 * * *$ \\
\hline SSE & $5.178 *$ & $5.337 *$ & 3.513 & 1.913 & $5.387^{*}$ & $9.585^{*}$ \\
\hline Trade & $16.490 *$ & $16.541 *$ & $14.377^{*}$ & $16.896^{*}$ & $12.852 *$ & $12.716^{*}$ \\
\hline FD (index) & $0.390 * *$ & $0.277 * *$ & $0.289 * *$ & $0.271 * *$ & & \\
\hline Inv. & & 0.016 & & & & \\
\hline FDI & & & $0.585^{*}$ & & & \\
\hline Govt. & $-19.345^{*}$ & & & & & \\
\hline Banking & & & & & $-0.901 * *$ & \\
\hline Currency & & & & & & $-5.670^{*}$ \\
\hline $\mathrm{R}^{2}$ & 0.3266 & 0.3267 & 0.355 & 0.401 & 0.447 & 0.684 \\
\hline
\end{tabular}

Fully Modified Ordinary Least Square (FMOLS) estimation technique, Dependent variable is real GDP per capita growth rate (Y_(i,t)), RIR in the real interest rate, Inf is the Inflation rate, Pop is the Population growth rate, Life is the log of life expectancy at birth, SSE is the secondary school enrolment ratio, Trade is the trade openness (exports + imports / GDP), Inv. is the domestic investment to GDP, Govt. is the Government expenditures to GDP, FDI is the foreign direct investment inflows, Banking and Currency are the dummy variables of Banking crisis and Currency crisis, respectively, Statistical significance at 1\%,5\% and 10\% is denoted by*, ** and *** respectively.

TABLE 4B

The Effect of Financial Development on Economic Growth

\begin{tabular}{|c|c|c|c|c|c|c|c|c|}
\hline \multirow[b]{2}{*}{ Variables } & \multicolumn{6}{|c|}{ Estimated Regressions } & \multicolumn{2}{|c|}{ (31- Developing Countries) } \\
\hline & 1 & 2 & 3 & 4 & 5 & 6 & 7 & 8 \\
\hline RIR & $-0.030 *$ & $-0.022 * * *$ & $-0.053 *$ & $-0.027 * *$ & -0.031 & $0.170^{*}$ & $-0.038^{*}$ & $-0.033^{*}$ \\
\hline $\operatorname{Inf}$ & -0.515 & -0.150 & -0.111 & $-0.644 * * *$ & 4.561 & $4.857^{*}$ & -0.330 & $-0.552 * *$ \\
\hline Pop & $-0.917 * *$ & $-0.821 * * *$ & & & $1.701^{*}$ & $-0.917 * *$ & -0.574 & $-0.899 * *$ \\
\hline Life & 14.553 & $19.412 * *$ & $17.326^{* * *}$ & $16.628 * * *$ & $88.97 * * *$ & $306.61 *$ & $25.486^{*}$ & $15.92 * * *$ \\
\hline Trade & $5.908^{*}$ & $3.988 * *$ & $3.347 * *$ & $3.865 * *$ & $3.773 * *$ & $7.963 * * *$ & $3.650 * *$ & $3.634 * *$ \\
\hline FD (index) & $2.172 *$ & $2.508^{*}$ & $1.221 * *$ & $2.281^{*}$ & $0.534 *$ & $55.215^{*}$ & $4.222 *$ & $2.908^{*}$ \\
\hline Inv. & & $2.263^{*}$ & & & & & & \\
\hline FDI & & & $1.288^{*}$ & & & & & \\
\hline Govt. & $-3.127 * *$ & & & & & & & \\
\hline Banking & & & & $-1.051^{*}$ & & & & \\
\hline Currency & & & & & $3.823 *$ & & & \\
\hline Private2 & & & & & & $-2.621^{*}$ & & \\
\hline FD2 (index) & & & & & & & & $1.790^{*}$ \\
\hline $\mathrm{R}^{2}$ & 0.268 & 0.276 & 0.326 & 0.277 & 0.456 & 0.582 & 0.317 & 0.267 \\
\hline
\end{tabular}

Fully Modified Ordinary Least Square (FMOLS) estimation technique, Dependent variable is real GDP per capita growth rate (Y (i,t)), RIR in the real interest rate, Inf is the Inflation rate, Pop is the Population growth rate, Life is the log of life expectancy at birth, Trade is the trade openness (exports + imports / GDP), Private2 represents credit booms to private sector in order to assess a threshold level, FD index is the aggregate index of financial development, FD2 (index) represents square of FD in order to assess a threshold level, Inv. is the domestic investment to GDP, Govt. is the Government expenditures to GDP, FDI is the foreign direct investment inflows, Banking and Currency are the dummy variables of Banking crisis and Currency crisis, respectively, Statistical significance at 1\%, 5\% and $10 \%$ is denoted by*, ** and $* * *$ respectively. 


\section{Estimation Results of Regression Models}

After evidencing the existence of Panel Cointegration between the variables, here we explore the estimation results of regressing the effect of FD on economic activities. The regression results show that the index shows a positive and significant relationship with economic growth in most of the models. These results are consistent with the view of Bagehot (1873), Gurley and Shaw (1955). It means that FD fuels the process of economic growth significantly in both groups of countries (see Tables $4 \mathrm{~A}$ and $4 \mathrm{~B}$ ). These results are also consistent with the results of Jalil and Ma (2008), and Jalil and Feridun (2011).

To examine the effect of investment efficiency on economic growth, we add the variable of the ratio of Domestic Investment to GDP in principal regression. The result gives a positive and significant sign with economic growth, for both groups of countries. It means the more the investment, the more will be capital accumulation, and hence it fuels to accelerate the process of economic growth.

To examine the effects of foreign cash inflows into the domestic financial economic system through financial institutions, we employed the variables of Foreign Direct Investment to GDP. The result gives a positive and significant sign with economic growth, for both groups of countries (see also 4A and 4B). It means that FDI accelerates the process of economic growth by generating more employment opportunities in real sector and financial sector as well, new production techniques, economies of scale, improving living standards, and rising per capita incomes of the population.

To examine the impact of government expenditures on the growth rate, we have employed the variable of Government expenditures to GDP. The results were found with appropriate negative and significant sign with economic growth for both groups, which may be due to the fact that the expenditures are takes place on non-development purposes and luxurious stuffs, which have no returns at all.

One thing that is worth noticing is to examine how much advancing credit to be funnelled to the private sector affects the FD, and hence the economic growth. We can see from the results that when we add both the indicator of credit to private sector to GDP and its square term in the main specification, we have different signs of private sector credit to GDP. On one hand, the variable of credit to private sector to GDP (also an indicator of FD) gives a positive and significant sign with economic growth for DCs. Which means the more the credit to private sector is; the more will be research and development, innovation, technological change, involving in new investment projects, leading to raise the capital accumulation and further accelerating the process of economic growth. However, the results are different for LDCs which gives insignificant positive sign (see Table 1). The reason can be that the governments of LDCs borrow most of their loans from their domestic banking sector and they are still imposing high reserve requirements and intervening in directing funds to some specific sectors (directed credit), which affects badly the availability of funds to be funnelled to the private sector by the banking institutions.

Whereas, on other hand, if we take the square of credit to private sector to GDP (representing Private credit booms), it gives a negative and significant sign with economic growth for both groups. Which means too much advancing credit to private sector leads to a financial crisis due to non-recovering of the credited loans in appropriate time period and leading to lack of funds to be given to depositors as rewards on their deposits. Furthermore, there will be more possibility of more defaulting loans of the financial institutions, which leads to insolvency of loans of the financial institutions. Another reason is that as we know that the government sector is also borrowing from commercial banks on a large scale and we also know that government sector is the most inefficient sector. So, when the government comes in competition with private sector in credit allocation, the government uses these borrowed funds into non-productive purposes. So, this is why too much credit harms the financial sector, and hence it deters the economic growth process by lowering the pace of capital accumulation.

However, if we take square of the aggregate FD index, it gives positive but insignificant sign with economic growth for DCs (see 4A). It means that more FD in the banking sector is beneficial for the advancement of economic growth, especially in DCs, but the sign is insignificant because they are Securities Market-Based economies; whereas, this sign is significant in case of LDCs in contrast having a Bank-Based financial system, that's why having a significant effect of too much FD (the mix of FD indicators, not the effect of a single one indicator) on economic growth (see Table 4B).

In this study, we have also employed financial crises dummies to examine the impact of financial crises on economic growth. These dummies includes; Banking crisis, Currency crisis, and Debt crisis. The regression results of these dummies gives negatively significant signs with economic growth, i.e., the year having any financial crisis would result in a negative impact on the economic growth (see Tables $4 \mathrm{~A}$ and $4 \mathrm{~B}$ ). Such relationship prevails for both groups i.e. DCs and LDCs, respectively.

By concluding the estimation results of examining the effect of financial development on economic growth, the results postulates that FD has a positive and significant effect on economic growth for both groups, 
i.e., Developed Countries (DCs) and Developing Countries (LDCs), having the desired appropriate signs of control and other affecting variables with economic growth rate. The results are consistent with that of the view ofMcKinnon(1973) and Goldsmith(1969), which means that FD plays a vital role in fuelling the process of economic growth.

\section{CONCLUSION}

This study explores to examine the impact of financial institutions sector development (FD) on economic growth for both groups of countries, especially in banking sector. Here by FD we mean that "the policies, factors, and the institutions lead to the efficient intermediation and effective financial markets, aiming to reduce market information acquisition costs and transaction costs, and other market imperfections. A strong financial institution offers risk diversification and effective resource allocation. The greater the FD, the higher would be the mobilization of savings and its allocation to high return projects and potential investments that further accelerates the process of growth (McKinnon, 1973, Goldsmith, 1969)."

The empirical results conclude that FD positively and significantly affects the growth process in both groups of countries. The results endorses the view of Bagehot (1873), Gurley and Shaw (1955), Jalil and Ma (2008), and Jalil and Feridun (2011), which means that FD plays a vital role in fuelling the process of economic growth. Similarly, one thing that is of immense interest that how much credit to private sector is to be credited (which shows the activity of credit allocation and intermediation taken as a proxy for FD), is beneficial for FD and further economic growth. So, the estimation results of both groups postulates that the boom in credit to private sector significantly affects negatively, which means it deters the financial sector development, and hence the pace of economic growth.

The results also infer that private credit booms may results in financial crash because of some reasons, such as; liquidity problems, huge public debt, insolvency, more defaulting loans, non-recovering of the credited loans, lack of funds to be given to depositors as rewards on their deposits, in appropriate time period and leading to lack of funds to be given to depositors as rewards on their deposits.

In nut-sum, "the impact of FD on growth may vary depending upon to whom the financial intermediaries are lending: to households, insurance companies, government sector or whether to investment companies. The lending takes place to households and insurance companies may lead to a decline in saving rate; hence, deter the investment level and the growth rate, whereas, if the lending takes place to investment entities, companies, or to the creation of stock markets, it is more likely to encourage growth. Hence, the theory concludes that the financial system simply contributes to industrialization, hence to accelerate economic activities, or in other words, FD is an immaterial rider to the process of economic growth."

\section{POLICY IMPLICATIONS}

The study on the role of financial institutions development on economic growth obviously has some policy implications for the policy makers and advisors attached to reforming financial sector policies. The evidences show significant influence of financial intermediary's sector development on economic growth, especially in Developing Countries (LDCs), because of being having dominantly Bank-Based financial systems or more developed banking sectors. As most of the literature highlights that crises were mostly due to large loses in output and huge public debts, which are resulted from deep banking systems that makes their banking systems more severe and disturbing (Kroszner, Laeven, \& Klingebiel, 2007); this study suggests some of crucial policy implications that are expected to exert a significant impact on FD, and further on the pace of economic growth.

Since, we know that the lower the gap between the lending interest rate and deposit interest rate, the higher will be the efficiency in the financial sector, so the policy recommendation here is to lower more the information acquisition and transactions costs along with lowering the spread between lending interest rate and deposit interest rate, in order to achieve more financial efficiency that leads to more FD that further fuels the process of economic growth.

Financial depth affects positively the economic growth through the channel that if the Time and saving deposits are to be intermediated to productive investment projects that reward higher returns, then it will accelerate the process of economic growth. So, here the policy recommendation is to funnel the Time and saving deposits (including in M2) to productive investments, that leads to raise the level of capital accumulation and hence to accelerate the economic growth process.

Avoiding credit booms, here the policy recommendation is to funnel funds to those sectors which use these funds productively and the credit intermediation should have some threshold level up to when the intermediating funds gives beneficial consequences.

Moreover, to nut-sum all the above points, here the policy recommendation is that there should be adequate banking supervision over the intermediation of funds, 
introducing reform policies, and credit allocation that are to be allocated to productive investments and ensuring that the bank had a well-diversified loan portfolio.

\section{LIMITATIONS AND FUTURE RESEARCH DIRECTIONS}

Since, any study cannot be perfect and sufficient, it must involve some shortcomings, flaws, limitations, and may depict one side of the story. These limitations may be due to the fact that to be very specific and to the point of interest may not lead him beyond the context. The limitation aspects can be: real and financial sectors, Bankbased or Market-based financial systems, cross-sections, time periods, variables, Socio-Economic aspects, welfare, environmental aspects, legal aspects, and many more. Similarly, this study also has some limitations. As far as this study is concerned, only with analysing the effects of banking sector development on economic growth process, rather than of securities market, or Bond market etc., it exempts some of the features and aspects, like social aspects of the economy and political forces (especially in developing or emerging economies, having a great influence on shaping financial sector policies and the operations of the financial institutions). So, their crucial themes are beyond the scope of this study. In nut sum, in this study we attempted to measure FD on the basis of observed outcomes of FD, but other measures were highly time invariant, like: country's legal, business, and political conditions.

Since any limitation existing in a study leads enough help for conducting research for future prospects; similarly, the limitations of this study also have strong links for conducting future researches in this regards. As the theory stresses that financial development influences the process of economic growth by affecting the main functions of financial institutions, such as: by easing the financial constraints and frictions (i.e. information and transaction costs), thereby to improve allocation of resources, risk management, diversifications, corporate control, governance, and financial exchanges. Since, the empirical literature does not capture the effects of these functions in measuring indicators of $\mathrm{FD}$, so there are more incentives to do work on this perspective in measuring indicators of FD. There is also an incentive for future research to be conducted by taking into account the political, legal, regulatory, cultural, and geographical perspectives which shapes FD.

\section{REFERENCES}

Aghion, P., \& Howitt, P. (1992). A Model of growth through Creative Destruction. Econometrica, Vol. 60 , No. 2, pp. 323-351.
Arrow, K. J. (1964). The role of securities in the optimal allocation of risk bearing". The Review of Economic Studies, Vol. 2, pp. 91-94.

Asteriou, D., \& Hall, S. G. (2011). Applied Econometrics, Second Edition.

Bagehot, W. (1873). Lombard Street, Homewood, IL: Richard D. Irwin (1873; 1962 edn).

Beck, T., Levine, R., \& Loayza, N. (1999). Finance and sources of growth. Journal of Financial Economics, Vol. 58, pp. 261-300.

Bencivenga, V. R., \& Smith, B. (1991).Financial intermediation and endogenous growth. The Review of Economic Studies, Vol. 58, pp. 195-209.

Boyd, J., \& Smith, B. D. (1992). Intermediation and the Equilibrium allocation of investment capital: Implications for economic development. Journal of Monetary Economics, Vol. 30, pp. 409-432.

Caprio, G., \& Klingebiel, D. (2003). Episodes of Systemic and Borderline Banking Crises. Mimeo: The World Bank.

Čihák, M., Demirguc-Kunt, A., Feyen, E., \& Levine, R. (2013). Financial Development in 205 Economies, 1960 to 2010. Journal of Financial Perspectives, EY Global FS Institute, Vol. 1, No. 2, pp. 17-36.

Creane, S., Goyal Rishi, A., Mushfiq, M., \& Randa, S. (2004). Financial sector development in Middle East and North Africa.International Monetary Fund, Washington, DC, IMF Working Paper, 04/201

Debreu, G. (1959). Theory of value. New York: Wiley. Demetriades, P.O., \& Hussein, K. A. (1996). Does Financial development cause economic growth? Time series evidence from 16 countries. Journal of Development Economics, Vol. 51, pp. 387-411.

Devereux, M. B., \& Smith, G.W. (1994).International risk sharing and economic growth. International Economic Review, Vol. 35, No. 4, pp. 535-550.

Friedman, M., \& Schwartz, A. J. (1963).A Monetary history of the United States. Princeton, NJ: Princeton University Press.

Goldsmith, R.W. (1969). Financial structure and development. Yale University Press, New Haven, CT.

Greenwood, J., \& Jovanovic, B. (1990).Financial development, growth, and the distribution of income. Journal of Political Economy, Vol. 98, pp. 1076-1107.

Grossman, G., \& Helpman, E. (1991).Quality ladders in the theory of Economic growth. Review of Economic Studies, Vol. LVIII, pp. 43-61.

Gurley, J. G., \& Shaw, E. S. (1955). Financial aspects of economic development. American Economic Review, Vol. 45, pp. 515-538.

Hassan, M., K., Sanchez., \& Jung-Suk Yu. (2011). Financial development and economic growth: New 
evidence from panel data. The Quarterly Review of Economics and Finance, Vol. 51, No. 1, pp. 88104.

Im, K. S., Pesaran, M. H., \& Shin, Y. (1997).Testing for Unit root in Heterogeneous Panels.MS, Department of Applied Economics, University of Cambridge.

Jalil, A., \& Feridun, M. (2011). Impact of Financial Development on economic grow th: Empirical evidence from Pakistan. Journal of the Asia Pacific Economy, Vol. 16, No.1, pp. 71-80.

Jalil, A., \& Ma, Y. (2008). Financial Development and economic growth: Time series evidence from Pakistan and China. Journal of Economic Cooperation, Vol. 29, No.2, pp. 29-68.

Kemal, A. R.., Qayyum, A., \& Hanif, M. N. (2004). Financial Development and Economic growth: Evidence from a Heterogeneous panel of high income countries. The Lahore Journal of Economics, Vol. 12, No. 1, pp. 1-34.

Keynes, J. M. (1930). A Treatise on Money. London: Macmillan.

Khan, M. A., Qayyum, A., \& Sheikh, S. A. (2005). Financial Development and Economic Growth: The Case of Pakistan.The Pakistan Development Review, Vol. 44, No. 4, part II, pp. 819-837.

King, R. G., \& Levine, R. (1993). Finance and Growth. Journal of Economics, Vol. 108, pp. 717-737.

King, R. G., \& Levine, R. (1993). Finance and growth: Schumpeter might be right. The Quarterly Journal of Economics, Vol. 108, No. 3, pp. 717-737.

King, R. G., \& Levine, R.(1993). Finance, Entrepreneurship, and growth. Journal of Monetary Economics, Vol. 32, pp. 513-542.

Krosner, R., Laeven, L., \& Klingebiel, D. (2007). Banking Crisis, Financial Dependence and Growth. Journal of Financial Economics, Vol. 84, pp. 187-228.

Kuznets, S. (1955). Economic growth and income inequality. American Economic Review, Vol. 45, pp. 1-28.

Laeven L., \& Valencia, F. (2012). Systemic Banking Crises Database: An update. IMF working papers, $\mathrm{Wp} / 12 / 163$

Levhari, D., \& Srinivasan, T. (1969).Optimal Savings under uncertainty. Review of Economic Studies, Vol. 36, pp. 153-163.

Levine, R. (1991).Stock markets, growth, and tax policy. Journal of Finance, Vol. 46, pp. 1445-1465.

Levine, R. (2003). Finance and economic growth: Theory, evidence, and Mechanism. Handbook of Economic Growth (Ch. 12) Brown University and NBER, Vol. 1A.

Lucas, R. Jr. (1988).On the Mechanism of Economic Development. Journal of Monetary Economics, Vol. 22, No. 1, pp. 3-42.
Lunitel, K. B., \& Khan, M. (1999). A Quantitative Reassessment of the Finance-growth Nexus: Evidence from a multivariate VAR. Journal of Development Economics, Vol.60, pp. 381-405.

McKinnon, R. I. (1973). Money and capital in economic development. Washington, DC: Brookings Institution.

Merton, R. C., \& Bodie, Z. (1995). A Conceptual Framework for analysing Financial Environment. In: Crane, D. B. et al. (eds.), The Global Financial System: A functional Perspective. Harvard Business School Press, Boston, MA, pp. 3-31.

Miller, M. H. (1998). Financial markets and economic growth. Journal of Applied Corporate Finance, Vol. 11, pp. 8-14.

Obstfeld, M. (1994). Risk taking, global diversification and growth. American Economic Review, Vol. 84, No. 5, pp. 1310-1329.

Pagano, M. (1993). Financial Markets and growth: An overview. European Economic Review, Vol. 37, pp. 613-622.

Patrick, H. (1966). Financial development and economic growth in Underdeveloped countries. Economic Development and Cultural Change, Vol. 14, No. 2, pp. 174-189.

Pedroni, P. (1997). Panel Cointegration: Asymptotic and finite sample properties of Pooled time series with an application to the PPP Hypothesis: New results. Working Paper, Indiana University.

Pedroni, P. (1999). Critical values for Cointegration Tests in Heterogeneous Panels with multiple Regressors. Oxford Bulleting of Economics and Statistics, Vol. 61, pp. 653-670.

Pedroni, Peter. (2000). Fully Modified OLS for Heterogeneous Cointegrated Panel. Advances in Econometrics, Vol. 15, pp. 653-70.

Rajan,R.,\&Zingalas,L.(1996).Financialdependenceand growth. University of Chicag. (Mimeographed)

Rajan, R., \& Zingales, L. (1998). Financial dependence and growth. American Economic Review, Vol. 88, pp. 559-586.

Ram, R. (1999). Financial development and economic growth:Additional evidence.JournalofDevelopment Studies, Vol. 35, No. 4, pp. 164-174.

Robinson, J. (1952). The Generalization of the General Theory; in the rate of interest and other essays. Macmillan, London, UK, pp. 67-142.

Romer, P. (1990). Are nonconvexities important for understanding growth? (No. w3271). National Bureau of Economic Research.

Rumer, P. M. (1986). Increasing returns and long-run growth. Journal of Political Economy (J.P.E), Vol. 94, No. 5, pp. 1002-1037.

Saint-Paul, G. (1992). Technological choice, financial markets, and economic development. European 
Economic Review, Vol. 36, pp. 763-781.

Schumpeter, J. A. (1911). The Theory of economic development. Cambridge: Harvard University Press.

Shan, J. (2006). Does Financial development leads
Economic growth? A Vector Auto-Regression Appraisal. Journal of Applied Economics, Vol. 37, pp. 1353-1367.

World Development Indicators (2011). Washington, DC: The World Bank. 